\title{
Planning of an Organisational and Post Structure for the Bureau of the Woordeboek van die Afrikaanse Taal (WAT)
}

\author{
D.J. van Schalkwyk, Editor-in-Chief, Bureau of the Woordeboek van die \\ Afrikaanse Taal, and M.T. Mey, Director, Organisation Development \\ Namibia Consultants
}

\begin{abstract}
Resulting from financial pressure and the desire to accelerate the completion of lexicographical projects, planning and management aspects are receiving increasing attention by lexicographical institutions. However, these important matters are not adequately emphasized at lexicographical conferences.

The topic of this article is the planning and management of a lexicographical project, especially the planning of its organisational and post structure. Although it here concerns the planning and management of the Bureau of the WAT, the views expressed can also be applied to other lexicographical projects.

The designing of an organisational and post structure of any institution is closely related to its strategic planning. The decision to adjust the organisational and post structure of the Bureau of the WAT logically resulted from its strategic planning which was done during 1989.

For the Bureau to give meaning to its endeavour and to perform its task, the organisational and post structure should meet the following requirements:

(i) Work processes, support systems and work ethics should focus on end results;

(ii) The editorial process should be accelerated with the aid of technology and editorial methodology;

(iii) Contextual relevance of the content of the WAT should be guaranteed;

(iv) The management culture should be user-driven; and

(v) A business management approach which supports cost sensitivity and which focuses on generation of income.
\end{abstract}

This article discusses the organisational and post structure which has been designed for the Bureau. of the WAT with these requirements in mind.

Because this article focuses on planners and managers of lexicographical projects and not in the first place on planning and management specialists, some ideas and standard details are being looked at more closely.

Keywords: STRATEGIC PLANNING, ORGANISATIONAL AND POST STRUCTURE, GROUP PLAN, LINE FUNCTION, STAFF SUPPORTING SERVICE, CRITICAL PERFORMANCE 
AREA, CRITICAL PERFORMANCE OUTPUT, SUCCESS INDICATORS, CONTROL INFORMATION, ORGANISATIONAL ANALYSIS, JOB EVALUATION, REMUNERATION STRUCTURE, REMUNERATION PACKAGE, ORGANISATIONAL DLAGRAM, JOB DESCRIPTIONS, ORGANISATIONAL ANALYSIS STATEMENT, KEY FUNCTIONS, PERFORMAŃCE MANAGEMENT SYSTEM, LEXICOGRAPHICAL PROJECTS

\section{Opsomming: Beplanning van 'n organisasie- en postestruktuur vir die} Buro van die Woordeboek van die Afrikaanse Taal (WAT). Veral vanweë finansiële druk en die begeerte tot versnelde voltooiing van leksikografiese projekte, kry beplanningsen bestuursaangeleenthede al meer aandag by leksikografiese instellings. Hierdie belangrike sake kry egter nog min aandag tydens leksikografiese kongresse.

Beplanning en bestuur van 'n leksikografiese projek, meer bepaald die beplanning van die organisasie- en postestruktuur, word in hierdie artikel onder die loep geneem. Alhoewel dit hier om die beplanning en bestuur van die Buro van die WAT handel, kan hierdie standpunte in ' $n$ mindere of meerdere mate ook vir ander leksikografiese projekte geld.

Die beplanning van die organisasie- en personeelstruktuur van 'n onderneming is onlosmaaklik verbonde aan sy strategiese beplanning. Die besluit om die Buro van die WAT se organisasie en postestruktuur aan te pas, het logies voortgevloei uit sy strategiese beplanning wat in 1989 gedoen is.

Indien die Buro inhoud wil gee aan sy strewe en sy taak tot uitvoer wil bring, moet sy organisasie- en postestruktuur aan die volgende eise voldoen:

(i) Werksprosesse, ondersteuningstelsels en werkskultuur moet op eindresultate gerig wees;

(ii) Die redaksionele bewerkingsproses moet met die hulp van tegnologie en bewerkingsmetodiek versnel kan word;

(iii) Kontekstuele relevan theid van die WAT-inhoud moet verseker word;

(iv) Gebruikersgerigtheid moet die wagwoord vir bestuursdenke wees; en

(v) 'n Sakebestuursbenadering wat die beginsel van koste en wins verreken, moet nagestreef word.

Hierdie artikel handel oor die organisasie en postestrukhuur wat met genoemde eise in gedagte vir die Buro van die WAT ontwerp is.

Vanweë die feit dat hierdie artikel vir beplanners en bestuurders van leksikografiese projekte geskryf is, en nie soseer vir beplannings- en bestuurskundiges nie, word sekere begrippe en standaarddetail in groter besonderhede hanteer.

Sleutelwoorde: STRATEGIESE BEPLANNING, ORGANISASIE- EN POSTESTRUKTUUR, GROEPPLAN, LYNFUNKSIE, STAFONDERSTEUNINGSDIENS, KRITIESE PRESTASIEAREA, KRITIESE . PRESTASIE-UITSET, SUKSESAANWYSERS, BEHEERINLIGTING, ORGANISASIEONTLEDING， POSWAARDERING，VERGOEDINGSTRUKTUUR，VERGOEDINGSPAKKET, ORGANISASIEDLAGRAM, POSBESKRYWINGS, ORGANISASIE-ONTLEDINGSTAAT, SLEUTELFUNKSIES, PRESTASIEBESTUURSTELSEL, LEKSIKOGRAFIESE PROJEKTE 


\section{Introduction}

In the past managers of lexicographical projects believed that the only solution to the slow alphabetical progress of dictionaries was an increase in staff members and working longer and harder.

This becomes clear when one scrutinizes literature on the topic. Often, emphasis is only placed on the editorially related functions performed during the production of a dictionary whilst the role of management work is underplayed.

In a recent publication Hartmann (1990: 74-75) identifies the following ten potential components for training courses in lexicography:

1. 'recording' (delimitation, gathering and processing of lexical data, including fieldwork and/or corpus collection),

2. 'description' (analysis, structuring and arrangement of processed material, including definition work),

3. 'presentation' (preparation of material for publication, taking account of target users' needs),

4. planning and organisation (including finance),

5. procedures and tools (including computing),

6. reflection and experimentation,

7. history of dictionary-making,

8. dictionary typology,

9. dictionary criticism,

10. dictionary use.

According to Hartmann (1990: 75) these components are "supplemented by reference to various contributing theoretical disciplines (such as linguistics and information technology) and strengthened by practical hands-on experience".

A supporting viewpoint emerged from the experience of the Bureau of the WAT. A recent formal review of the Bureau's strategic focus and the extent to which its organisational structure and work procedures are aligned with its short and long-term strategies, revealed that any substantial lexicographic project with a longer term orientation should take cognisance of modern management approaches and techniques. During its own strategic planning exercise (Buro van die WAT 1989: 71), the Bureau of the WAT identified the following functional areas within which it has to pursue its aims and objectives:

Tasks related to its unique professional function: Collection of material, editing, typesetting, reproduction and binding.

Tasks related to technical and administrative support functions: Marketing, language advisory service, research, finance, administration and logistical support as well as planning and control. 
It is significant that Hartmann's ten potential components for training courses in lexicography can be reconciled with the above-mentioned focus areas of the Bureau of the WAT.

Planning and control are generic components of management work and actually cannot be regarded as a separate functional area.

According to annual reports of lexicographical institutions, management has become a very important matter especially resulting from financial pressure and the desire to accelerate the completion of projects. The "Meerjarenplanning" of the Woordenboek der Nederlandsche Taal (Secretariaat van de Stichting 1989: 30) is an example of this tendency. Nevertheless, according to Hartmann's review of conferences which were held between 1960 and 1988 (Hartmann 1988), management did not feature as a topic or conference theme at any of these conferences. This emphasises the fact that management in terms of lexicographical reasoning has not yet received adequate attention.

The aim of the present article is to share the experience of the Bureau of the WAT in applying modem business planning and organisational principles and methods in the restructuring of a lexicographical project. It is not the intention to make a unique contribution to management literature. The article's focus is, however, on the planners and managers of other lexicographical projects. For their benefit the process which was followed, is described and recorded in detail. Furthermore, the results of only some of the most meaningful internal management reforms will be discussed.

\section{Strategic organisational planning}

The designing of an organisational and post structure of any institution is directly related to its strategic planning. Consequently the decision to adjust the organisational and post structure of the Bureau of the WAT resulted from its strategic planning project which was commenced with during 1989.

\section{Mission and task of the Bureau of the WAT}

In accordance with the statutory object of the Bureau its mission was formulated as follows:

The Bureau of the WAT STRIVES to serve the Afrikaans language and its users. 
Its TASK is to pursue the following broad objectives:

1. to continue, to complete as soon as possible, and from time to time improve the compilation of the WAT by

(a) the continuous, representative and comprehensive collection, arrangement and storage in a lexicographically workable form of the vocabulary of the Afrikaans language; and

(b) the editing of the collected material according to scientifically established lexicographical principles in the form of an authoritative, user-friendly, synchronic explanatory dictionary in consecutive volumes;

2. to produce the WAT cost-effectively;

3. to market the WAT dynamically;

4. to grant controlled access to the language material and sources of the Bureau to bona fide researchers and to answer linguistic enquiries;

5. to liaise with South African and overseas lexicographic and other linguistic institutions with a view to exchanging lexicographical knowledge, information and publications;

6. to act as a growth point and stimulus for lexicographical activities and lexicological thought; and

7. to establish and promote a positive corporate image of the Bureau.

\section{Requirements for success}

In the light of the mission and objectives of the Bureau of the WAT the organisational and post structure should meet the following requirements:

(i) Work processes, support systems and work ethics should focus on end results;

(ii) The editorial process should be accelerated with the aid of information technology;

(iii) Contextual relevance of the content of the WAT should be guaranteed;

(iv) The management culture should be user-driven; and

(v) A business management approach which supports cost sensitivity and which focuses on generation of income.

These requirements for success form the overall criteria for the operating processes of the Bureau.

The Verslag oor ' $n$ rasionele organisasie- en personeelstruktuur vir die Buro van die Woordeboek van die Afrikaanse Taal (Buro van die WAT 1990) reports on the 
organisational and post structure which was developed for the Bureau with these aims in mind. The following discussion is closely linked to this report.

\section{The organisational and post structure of the Bureau: 1989}

Up to 1989 the organisational and post structure of the Bureau was linear. It mainly consisted of an editorial component. Such a linear structure is typical of an organisation in an early stage of its life-cycle when functional differentiation and specialisation are virtually non-existent (Lievegoed 1979: 2).

This structure had the following consequences:

(i) The editors were involved in every phase of the lexicographical process and this had a negative effect on the pace of manuscript production;

(ii) At the same time non-editorial tasks were delegated to the editors. This had a straining effect on their capacity to devote maximum time to the editorial process.

An analysis of the external environment reveals new demands and challenges that the Bureau has to face to remain viable in future. Accordingly an internal audit of work procedures and structuring of functions during the process of strategic planning pointed out the necessity for a distinct differentiation of functions on horizontal and vertical organisational levels. A few of these factors will now be discussed.

6. Reasons for reviewing the organisational and post structure of the Bureau of the WAT

\subsection{Introduction of computer technology}

The Bureau started during 1987 with computerisation. It became clear that computerisation would not only accelerate the editorial process but it was also perceived as a prerequisite for cost-effective production of publications. As a matter of fact, electronic layout of the dictionary became a necessity to eliminate time-consuming processes such as the composition of galleys and page proofs.

Consequently the following conditions had to be fulfilled:

The Bureau:

(i) had to have customized computer hardware and software,

(ii) had to have efficient, trained staff to operate the hardware and software in the most effective way,

(iii) had to be capable of maintaining the hardware and software, 
(iv) had to stay in touch with the latest computer developments in order to be able to continually identify the most appropriate technology for the Bureau.

It was realised that the Bureau could assign some of these tasks, such as the development of systems and expert software programs, to external contractors. Routine maintenance, system control and surveying of appropriate reprographical processes, however, should preferably be done internally.

Neither the capacity nor the know-how was provided for in the existing structure of the Bureau.

\subsection{Institutionalisation of non-traditional functions}

The repositioning of the Bureau as a self-managing lexicographic concern led to the differentiation of functions like marketing as well as personnel and accounting services.

Reproduction and distribution of the WAT were in the past done by the Government Printer of South Africa. Since 1986 the Bureau had to accept responsibility for the marketing function which was identified during the strategic planning exercise as a critical performance area in a new dispensation.

The traditional task of the Bureau, however, does not make provision for responsibilities such as the designing of a marketing policy and strategy, and the continuous implementation of marketing actions. These tasks were not formally assigned to a post in the existing structure and skills as well as capabilities were lacking among staff members.

Personnel and accounting services were neither formalised as part of the internal organisation of the Bureau nor did it have an administrative component to handle these matters.

The Department of Finance of the University of Stellenbosch assisted and still assists the Bureau in routine financial administrative matters such as budget maintenance and compilation of financial reports, whereas budget planning and control had to be done by the Bureau itself.

In the case of personnel services the Bureau has to perform all functions internally.

\subsection{The position of the Editor-in-Chief}

Incorporation of new functions and formalisation of obligations as a self-managing unit by the Bureau have a marked effect on the future role and responsibilities of the Editor-in-Chief.

Previously the Editor-in-Chief's responsibility for the final editing of all manuscript as well as galley and page proofs occupied most of his time. As a 
result of the many management and administrative responsibilities which were in the course of time assigned to the Editor-in-Chief, a far-reaching rationalisation of his functions became a necessity. This, however, did not differ from his activities and duties as laid down in the "Woordeboek van die Afrikaanse Taal" Act, 1973 (Act 50 of 1973).

According to this Act the official duties of the Editor-in-Chief are formulated as follows:

(a) to direct the bureau and to carry out its object in accordance with the policy laid down by the board; and

(b) to furnish the board with an annual report on the activities and financial position of the bureau.

The following management tasks of the Editor-in-Chief result from the above mentioned duties:

(i) Managing of change by a continuous scanning of the external environment and construction of scenarios in order to keep the institution on an even keel;

(ii) The formulation of the corporate identity and the development of the corporate image of the Bureau;

(iii) The transformation of the image of the Bureau from a government institution to an enterprise with a product and market orientation;

(iv) Liaison not only with language users, potential buyers of the Woordeboek and the commercial sector, but also with South African and overseas linguists and especially lexicographers; and

(v) The development of marketing and financial strategies and their implementation.

With the imposition of these management responsibilities the role of the Editor-in-Chief has made its final transition to become that of Chief Executive Officer of the Bureau of the WAT. This resulted in a redefinition of the roles and responsibilities assigned to all the other key positions in the Bureau.

Against this background it was decided to revise the organisational and staff establishment.

\section{The investigation}

\subsection{The utilization of external skills}

The designing of a functional and organisational structure and the subsequent processes of structuring and evaluation of posts as well as the defining of a remuneration structure require specialist skills. Hence the Bureau made use of 
the help of external consultants.

\section{Methodology of structural design}

As mentioned earlier, the decision to revise the functional and organisational structure logically resulted from the strategic planning of the Bureau. It was clear that the previous structure could not cope with the new demands of a self-governing organisation.

The greater emphasis on results and the urgency of self-sufficiency led to a reconsideration of the role and function of key posts and of the effectiveness of work procedures. The Bureau as a skill-driven organisation realised that a rational organisational structure and supportive processes had to be created which would ensure that the talents and energy of the staff would be developed and remain focussed on end results. Consequently it was decided to use natural work groups in the work analysis process. As a matter of fact the essence of the lexicographical industry is focussed on the interdependence of editorial team members who support each other mutually. The structure and work procedures of such undertakings must therefore support the accomplishment of effective team work which at the same time will satisfy the individual's need for self-development.

A natural work group is defined as "three or more persons joined together to work toward a common goal or purpose" (Mink et al. 1987: 17). Work analysis with the working group as basis gives the analyser perspective on the logical flow of work within the context of the total system. Simultaneously group members will get a clear view on the interrelationship between the various tasks and responsibilities with regard to the common goal. During this process, unique performance areas for each group and post are defined, and interfaces between work units are made clear in order to obviate duplication of work, and also to create mutual support. This "bottom-up" approach ensures that the differentiation among managerial and production work can be made more sensible (Schutte 1981: 27).

A process which is known as "Integrated Performance Management", with group dynamics as an implementing mechanism, was followed. It has been developed by the Organisation Development Consultancy Service of Finansbank, SA, and it consists of the following components (Finansbank s.a.):

(i) Development of group plans which specify the end results and performance standards of each natural work group;

(ii) Implementation of supportive group processes, inter alia team-oriented problem solving, performance evaluation and goal setting procedures; and

(iii) Integration of these supportive processes in a performance management approach. 


\subsection{Development of group plans}

An analysis of all the work that should be done if the Bureau wished to attain its endeavour and task, was carried out. Tasks and activities were grouped in so-called CPA's (Critical Performance Areas) as principal functions which must be performed to execute line-technical and staff-supporting work (Mintzberg 1983: 12-13). Staff of the Bureau, with the aid of an external facilitator, completed this analysis and systematization of work, taking into account the Bureau's future position as anticipated during its strategic planning.

Upon completion of the analysis the functional grouping of the Bureau's work was divided into three sectors, viz.:

(i) Editorial processing as the line function;

(ii) Editorial support services as the technological supporting component; and

(iii) Administrative support services as a staff supporting service.

Group plans were compiled according to a standard format. All the work that had to be performed collectively by a particular work group of the Bureau was explicated in the following logical order:

(i) Critical Performance Areas (CPA's), as main functions or principal components of work that the specific division must do in order to directly contribute to the attainment of the Bureau's overall aim and task;

(ii) Critical Performance Outputs (CPO's) as the end results when all the work in a particular CPA has been done satisfactorily;

(iii) Success indicators, as indicators that could be observed to monitor successful attainment of results;

(iv) Standards, as measurement criteria for each result; and

(v) Control information, in the form of reports, statistics or other evidence that could be used to record performance.

\subsection{Organisational structure}

The next step was to allocate work assigned to group plans to individual posts. Critical Performance Areas and Critical Performance Outputs of editorial processing, editorial support services and administrative support services were subdivided into management and technical work which must be done within a specific post, in order to provide work satisfaction to the individual and to ensure a contribution to the achievement of end results. tion:

The following departure points were pursued in structuring the organisa- 
(i) An ideal structure should be designed that will support the long-term aims of the Bureau, even though certain components would not be completely activated in the short term; and

(ii) Acknowledged principles of rational development of organisational structures should be aimed at, e.g. maximum span of control, a minimum of management levels, grouping of homogeneous work, allocation of unique responsibilities to each post and acceptance of the principle of completed work (Mintzberg 1979: 104-133).

At the same time, it was realised that the Bureau's future environment will demand dynamic adaptation in the deployment of the ideal structure. As a result, provision had to be made for a phasing-in process, and also for a flexible approach in order to enable the Bureau to meet new demands immediately.

\subsection{Organisational analysis}

An analysis of formal relationships (responsibility, authority and accountability) among the identified posts was made to ensure that the overlapping of areas could be obviated and accountability for completed work could be clearly established.

Responsibility can be seen as the work that has been assigned to a post; authority can be described as the right to decide what must be done and the right to do it or to delegate it to someone else to do the work; and accountability as the obligation to remain responsible for results even though one has delegated tasks.

The technique used to analyse interrelationships is referred to as LRC (Linear Responsibility Charting). It consists of a grid that is compiled to display the interfaces between posts on the organisation chart. This grid indicates who participates to what degree when an activity is performed or a decision made (Finansbank 1982: 18-22).

\subsection{Job evaluation}

The final process utilized in the restructuring of the Bureau, was the formal evaluation of all posts. For this purpose, the Peromnes evaluation technique was used. It is one of the techniques generally used in South Africa for this purpose (FSA-Contact 1986).

Evaluation of posts is the process whereby the complexity of the content of posts is determined according to the same set of criteria. It enables the management of an organisation to adopt a fair remuneration package, which acknowledges the inherent variation in the degree of complexity among posts. At the same time, it contributes to the development of a logical structure of 
posts on which other personnel management processes can be based.

A standard scale of evaluation was used to evaluate each post. The following factors were taken into account:

(i) Problem solving

(ii) Results of judgement errors

(iii) Work pressure inherent in the post

(iv) Level of operational knowledge

(v) Internal and external impact of the post

(vi) Understanding of written and oral communication

(vii) Qualifications

(viii) Experience

No further reference will be made in the present report on the outcome of job evaluation. Therefore it is necessary to point out that the job evaluation panel adopted a strategy of conservative grading of posts.based on established job content, which was also perceived to form part of performance requirements in the immediate future. The job grades of newly created posts were subjected to verification after a period of time had elapsed.

\section{Discussion of a few results}

\subsection{Group plans}

In its publication ' $n$ Geintegreerde prestasiebestuurstelsel Finansbank (s.a.: 11) says with regard to group plans: "Group plans supply a logical and systematic analysis of the results which must be attained by the persons involved. It takes the work that has to be done as the point of departure and deduces it to wider results which are again deduced to specific measurable results."

The performance areas of marketing, personnel, finances, planning and control were assigned to the office of the Editor-in-Chief and the Administrative Support Services. Collection of material, layout, printing and binding of the WAT, language services and supportive services have all been assigned to the division Editorial Support Services, and editorial processing and research to the division Editorial Processing.

The group plans which have been developed in connection with the respective critical focus areas, are too comprehensive to detail in this article. Therefore, only those areas which have a bearing on the line function of the Bureau, i.e. editorial processing, will be discussed. 


\subsection{Group plan: editorial processing}

The editorial division of the Bureau of the WAT consists, at present, of four CoEditors, two Senior Co-Editors and a Final Editor. Two Co-Editors together with a Senior Co-Editor form an editorial team. The Final Editor does the functional planning of, and exercises control over the editing component, while the Editor-in-Chief is responsible for overhead quality control and for certifying manuscript as correct for publication.

In the table of the Functional Group Plan: Editorial Processing (see Appendix B), the following data have been taken into account:

(i) Critical Performance Areas (CPA's) of the editorial division, i.e. systematisation, production of manuscript and editing, as principal functions or main groupings of work which the particular division must do in order to directly contribute to the attainment of the Bureau's endeavour and task;

(ii) The Critical Performance Outputs (CPO's) which are the end results when all the work in a CPA has been completed satisfactorily;

(iii) Success indicators which indicate that the CPO's have been achieved;

(iv) Standards which are "the specific criteria that are used by individuals and groups to measure real achievement of Critical Performance Outputs" (Finansbank s.a.: 18); and

(v) Control information which is "the medium used by individuals and groups to relate real outputs with required outputs" (Finansbank s.a.: 21).

\subsection{Staff establishment of the Bureau of the WAT}

\subsubsection{Posts which are critical for the effective functioning of the Bureau}

For the proper functioning of the three divisions of the Bureau, the following posts have been created:

(i) In the division Editorial Processing there are nine posts, i.e. one Final Editor, two Senior Co-Editors and six Co-Editors. Posts allocated to perform a language advisory service should also resort under this division. However, it was decided to allocate staff control with respect to these posts to the division of Editorial Support Services, in order to alleviate demands on the supervisory obligations of the Final Editor;

(ii) In the division Editorial Support Services, there are four posts, i.e. Manager: Editorial Support Services, System Manager, Controller: Information Support Service and Senior Data Typist; 
(iii) In the division Administrative Support Services, there are five posts, i.e. Editor-in-Chief, Office Manager, Senior General Assistant, Secretary and a Typist.

\subsubsection{Temporary staff}

The Bureau utilizes the following temporary staff for routine production work:

Excerptors, who collect material from language sources,

Card Selectors, who process and select material which has been written on cards,

Material Controllers, who check the selected material against the sources for correctness,

Data Typists, who capture the data on computer,

Correctors, who verify the recorded data in printed form against the sources for correctness, and

Specialist Advisors, who check the definitions of technical terms for correctness.

\subsection{Organisational diagram of the Bureau of the WAT}

Posts in the organisational diagram (see Appendix A) are not portrayed in a hierarchical order.

\subsection{Job descriptions}

After the responsibilities, authority and accountability attached to the respective posts had been identified, job descriptions were compiled for all posts. Each job description includes the key functions of the post, as well as an incumbent profile. In the incumbent profile, matters such as educational qualifications, experience, as well as capabilities and skills of the incumbent are included. The latter also includes technical or functional skills, conceptual skills, interpersonal skills and a personality profile.

With respect to the performance area of editorial processing, the key functions of the Co-Editors and Senior Co-Editors comprise the processing of manuscript material. This includes the conceptualisation of the meaning and semantic structure of lemmas, the verification of this meaning and its semantic structure, as well as the production of verified articles.

In the job description of the Final Editor, key functions with reference to editorial processing are set out below: 
(i) Advisory role in processing manuscript material

(a) Discusses problematic simplexes and other material with the editorial teams;

(b) On request gives advice pertaining to the semantic structure and processing of articles.

(ii) Editing of manuscript material

(a) Verifies the conceptualized articles;

(b) Finalises the manuscript according to typographic and editorial prescriptions;

and

(c) Proof-reads the manuscript.

The key functions of the Editor-in-Chief with reference to the editorial process include the following:

(i) Responsible for overall quality control. This function is exercised by means of random checks.

(ii) Certifies the manuscript as correct for publication.

\subsection{Areas of common interest between the Board of Control of the WAT and the Bureau}

The Bureau is controlled by a board which is known as the Board of Control of the "Woordeboek van die Afrikaanse Taal" (Act 50, 1973, sect. 4). The areas of common interest between the Board of Control and the Bureau were deduced from this Act as amended. A relationship analysis was done and the results can be stated as follows:

\subsubsection{Prime responsibility of the Board of Control}

In terms of the above-mentioned Act, the Board of Control's prime responsibility is to keep the Bureau of the WAT focused on its aim and objects by means of policy measures and an annual budget. At the same time, the Act determines that the Board of Control should approve the staff establishment to enable the Bureau to perform its task. Achievement is monitored both by statutorily required reports and financial statements, as well as by means of strategic management information which is periodically given to the Administrator by the Editor-in-Chief. The nature, scope and frequency of this reporting 
is determined by the Administrator and the Editor-in-Chief.

During periods between the Board of Control's meetings the chairman of the Board of Control acts as Administrator. During such periods he performs all the functions and exercises all the powers of the Board of Control (Act 50, 1973, sect. 8).

8.6.2 Summary of delegated responsibilities and authority as deduced from the Act

1. FINANCIAL MATTERS

a. Structuring, preparation and submission of the budget to the Board Editor-in-Chief

b. Approval of the budget Board of Control

c. Administration of the budget Accountant (contracted out)

d. Exercise of budget control

Editor-in-Chief

e. Approval of expenses

Editor-in-Chief

f. Submission of statutory reports

Editor-in-Chief

\section{STAFF MATTERS}

a. Appointment of Editor-in-Chief, Final Editor, Senior Co-Editors and Manager: Editorial Support Services

Board of Control

b. Appointment and promotion of the rest of the Bureau Staff

Editor-in-Chief

c. Designing of salary structure and conditions of service

Editor-in-Chief

d. Approval of salaries and salary scale adjustments

Board of Control 
e. Salary adjustments - annual individual adjustments

Administrator

3. MARKETING AND SALES

a. Marketing policy and strategy (edition, selling price and conditions of sale)

Board of Control

b. Designing and implementation of marketing program

Editor-in-Chief

4. MANAGEMENT MATTERS

a. Strategic policy determination

Board of Control

b. Organisational structure and conditions of service

Board of Control

9. Phasing-in of the new organisational and post structure

Often excellent organisation studies end up in filing cabinets because no provision was made for proper control of the implementation of recommendations. In the case of the Bureau of the WAT, a phasing-in strategy has been developed which specifies and schedules steps that have to be taken in commissioning the new structure.

Careful attention was given to affordability of the suggested staff establishment and implementation of amended service conditions as well as the definition and clarification of roles.

\section{Preliminary results}

This organisational and post structure was implemented at the Bureau of the WAT in November 1990. An integrated performance management system with which the output of the staff can be monitored, was adopted in July 1991.

A longer period of time is needed to evaluate the organisational and post structure thoroughly. Some aspects of this structure, such as the re-evaluation of posts, must be followed up. However, the following results have already been obtained:

(i) Editorial groups are functioning effectively. 
(ii) Production standards as well as continuous evaluation of what has been done to achieve these standards, led to a more prominent focus on end results.

(iii) Nine months after the implementation of production standards, all editorial staff members were able to maintain these standards.

(iv) One year after production standards had been introduced, half of the editorial staff exceeded these standards by $50 \%$. It is clear that production and quality standards can not be separated from each other.

These positive results show that continuous evaluation of the new organisational and post structure of the Bureau of the WAT can be rewarding.

\section{References}

Buro van die WAT. 1989. Verslag oor die strategiese beplanning oir die Buro oan die Woordeboek oan die Afrikaanse Taal. Unpublished report. Stellenbosch: Buro van die WAT.

Buro van die WAT. 1990. Vetslag oor 'n rasionele organisasie- en personeelstruktuur vir die Buro zan die Woordeboek van die Afrikanase Taal. Unpublished report. Stellenbosch: Buro van die WAT.

Finansbank. s.a. ' $n$ Getintegreetde prestasiebestuurstelsel. Johannesburg. The Penrose Press.

Finansbank. 1982. Handleiding vir die beplanning oan 'n organisasiestruktuur vir die Afdeling Bankdienste, Finansbank. Unpublished report. Johannesburg: Finansbank.

FSA-Contact. 1986. Peromnes Job Evaluation Scale. Johannesburg: FSA-Contact.

Hartmann, Reinhard. 1990. The Organisation of Lexicography in Africa. Hartmann, R.R.K. (Ed.). 1990. Lexicography in Africa. Exeter Linguistic Studies 15: 66-75. Exeter: University of Exeter Press.

Hartmann, R.R.K. 1988. A Quarter of a Century's Lexicographical Conferences. Magay, T. and J. Zigány (Eds.). 1988. BudaLEX '88 Proceedings: Papers from the 3rd International EURALEX Congress, Budapest, 4-9 September 1988: 569-574. Budapest: Akadëmiai Kiadó.

Lievegoed, B.C.J. 1979. Development Phases of Organisations. Unpublished article of NPI, Zeist, the Netherlands.

Mink, O.G., B.P. Mink and K.Q. Owen. 1987. Groups at Work. Englewood Cliffs, New Jersey: Educational Technology Publications.

Mintzberg, H. 1979. The Structuring of Organizations. Englewood Cliffs, New Jersey: Prentice Haill, Inc.

Mintzberg, H. 1983. Structure in Fioes: Designing Effectioe Organizations. Englewood Cliffs, New Jersey: Prentice Hall, Inc.

Schutte, F. Grant. 1981. Integrated Management Systems. Durban: Butterworths.

Secretariaat van de Stichting. 1989. Jaarboek pan de Stichting Instituut ooor Nederlandse Lexicologie. Ooerzicht oan het joar 1988. Leiden: Secretariaat van de Stichting.

"Woordeboek van die Afrikaanse Taal" Act, 1973. (Act 50 of 1973).

"Woordeboek van die Afrikaanse Taal" Amendment Act, 1986. (Act 9 of 1986). 


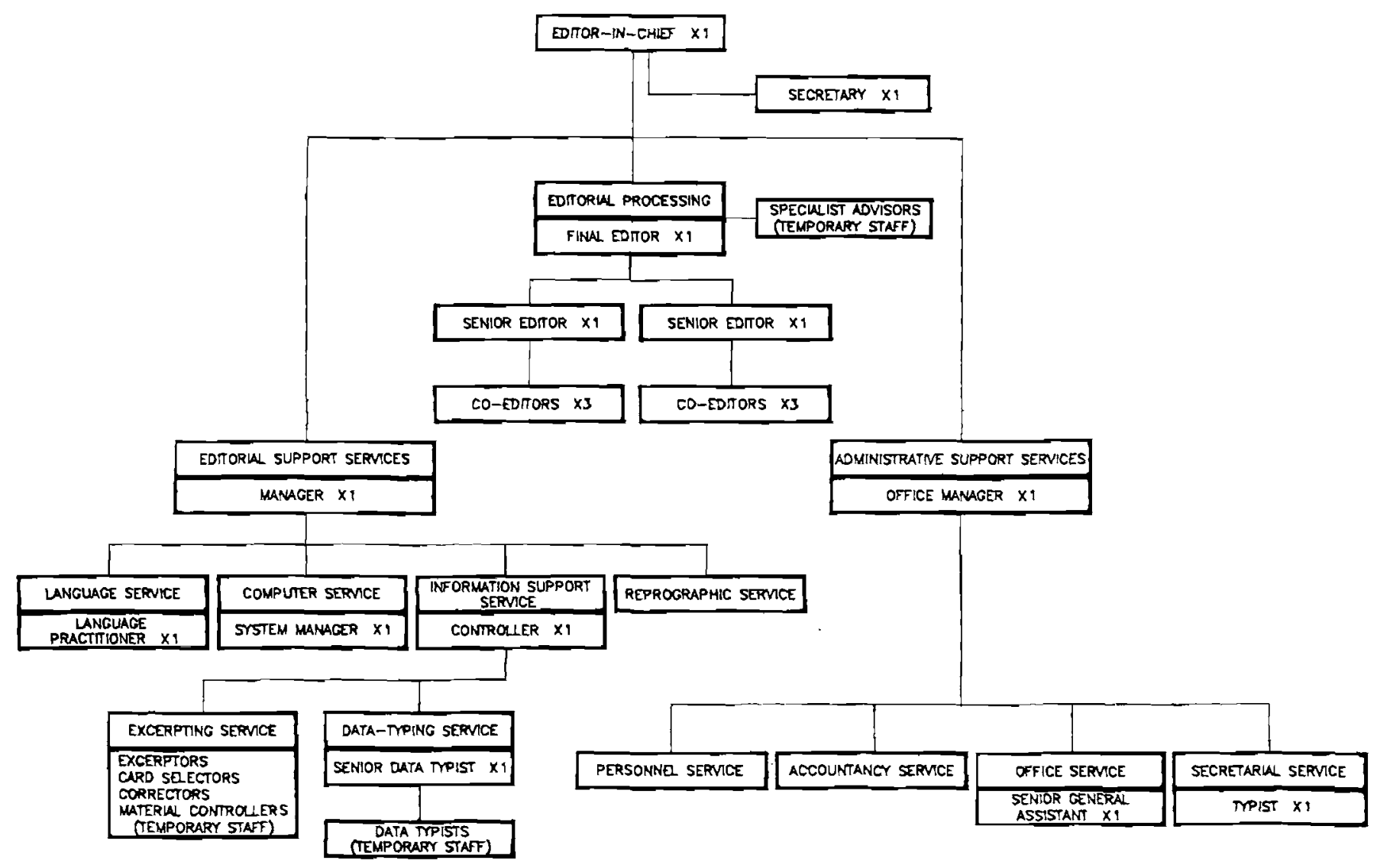




\begin{tabular}{|c|c|c|c|c|}
\hline \multirow[t]{6}{*}{ I. Systematisation } & \multirow{6}{*}{$\begin{array}{l}\text { Selected and examined } \\
\text { material, preliminarily } \\
\text { classified according to } \\
\text { the field of entry and } \\
\text { meaning differentia- } \\
\text { tion. }\end{array}$} & $\begin{array}{l}\text { At a specific point in } \\
\text { time all lemmas were } \\
\text { soned out in accordance } \\
\text { with the inclusion policy. }\end{array}$ & $\begin{array}{l}\text { - Before starting on the production of } \\
\text { manuscript, all lemmas should be } \\
\text { soned out according to the inclusion } \\
\text { policy. }\end{array}$ & $\begin{array}{l}\text { - Report to the editorial team } \\
\text { every time production of } \\
\text { manuscript is stanted or at the } \\
\text { completion of an assigrment. }\end{array}$ \\
\hline & & $\begin{array}{l}\text { * The context of the } \\
\text { quotation clearly } \\
\text { reveals the meaning of } \\
\text { the lemma. }\end{array}$ & $\begin{array}{l}\text { The meaning of the lemma as } \\
\text { revealed in the original source } \\
\text { of the quotation, should be obtain- } \\
\text { able from the record without any } \\
\text { further reference. }\end{array}$ & $\begin{array}{l}\text { "Continuous evalpation with } \\
\text { regard to usability. }\end{array}$ \\
\hline & & $\begin{array}{l}\text { A computer record pro- } \\
\text { vides useful information } \\
\text { for the editorial } \\
\text { process. }\end{array}$ & $\begin{array}{l}\text { The information on a lemma to which } \\
\text { a compuler record refers, should be } \\
\text { obtainable from the record without } \\
\text { any further reference. }\end{array}$ & \\
\hline & & $\begin{array}{l}\text { + Information was selected } \\
\text { according to the revised } \\
\text { editorial system. }\end{array}$ & $\begin{array}{l}\text { * There should be no discrepancy } \\
\text { between the selected information } \\
\text { and the revised editorial system. }\end{array}$ & \\
\hline & & $\begin{array}{l}\text { Material was classified } \\
\text { according to word-classes. }\end{array}$ & $\begin{array}{l}\text { The classification of material was } \\
\text { done in accordance with the current } \\
\text { principles of word-class } \\
\text { classification. }\end{array}$ & $\begin{array}{l}\text { Continuous review } \\
\text { with regard to } \\
\text { correctness. }\end{array}$ \\
\hline & & $\begin{array}{l}\text { - Differentiation in } \\
\text { meaning correlates with } \\
\text { quotations. }\end{array}$ & $\begin{array}{l}\text { No discrepancy between the contents } \\
\text { of the quotations and the } \\
\text { differentiation in meaning. }\end{array}$ & $\begin{array}{l}\text { * Continuous evaluation with } \\
\text { regard to comelation. }\end{array}$ \\
\hline
\end{tabular}




\begin{tabular}{|c|c|c|c|c|}
\hline \multirow[t]{3}{*}{$\begin{array}{l}\text { 2. Manuscript } \\
\text { production }\end{array}$} & \multirow[t]{3}{*}{ Finalised anticle } & $\begin{array}{l}\text { The structure of meaning } \\
\text { is confirmed by the } \\
\text { quotations. }\end{array}$ & $\begin{array}{l}\text { "No discrepancy between the struc- } \\
\text { ture of meaning and quotations. }\end{array}$ & $\begin{array}{l}\text { Continuous evaluation with } \\
\text { regard to correlation. }\end{array}$ \\
\hline & & $\begin{array}{l}\text { * Article entries are veri- } \\
\text { fied by quotations, in- } \\
\text { clusion policy and the } \\
\text { editorial system. }\end{array}$ & $\begin{array}{l}\text { - Article entries correlate with } \\
\text { contents of quotations and the } \\
\text { requirements as stated in the } \\
\text { inclusion policy and editorial system. }\end{array}$ & $\begin{array}{l}\text { Evaluation of correlation on } \\
\text { completion of the article. }\end{array}$ \\
\hline & & & $\begin{array}{l}\text { A single editorial team must process } \\
\text { the cards of approximately one } \\
\text { drawer in the form of manuscript per } \\
\text { month, which will produce } 66.5 \text { pages } \\
\text { of computer printout and } 10 \text { two- } \\
\text { column dictionary pages. }\end{array}$ & $\begin{array}{l}\text { Monthly report on the pro- } \\
\text { gress of manuscript produc- } \\
\text { tion and achievement of } \\
\text { standards. }\end{array}$ \\
\hline \multirow[t]{3}{*}{ 3. Editing } & \multirow[t]{3}{*}{ Approved manuscript } & $\begin{array}{l}\text { Conceptualization forms } \\
\text { a meaningful whole. }\end{array}$ & $\begin{array}{l}\text { - Meaningful integration of all } \\
\text { information inlo the article. }\end{array}$ & $\begin{array}{l}\text { * Repont before forwarding for } \\
\text { final approval by Editor-in- } \\
\text { Chief. }\end{array}$ \\
\hline & & $\begin{array}{l}\text { Manuscript conforms to } \\
\text { editorial system. }\end{array}$ & $\begin{array}{l}\text { - No discrepancies between manu- } \\
\text { script and editorial systern. }\end{array}$ & $\begin{array}{l}\text { * Test-check by Editor-in- } \\
\text { Chief. }\end{array}$ \\
\hline & & & $\begin{array}{l}\text { Manuscript production of the two } \\
\text { editorial teams (133 pages of } \\
\text { computer prinlout) is continously } \\
\text { edited in consultation with the teams } \\
\text { in order to finalise the reprographi- } \\
\text { cal processes as quickly as possible. }\end{array}$ & $\begin{array}{l}\text { - Monthly report on the } \\
\text { achievernent of standards. }\end{array}$ \\
\hline
\end{tabular}

